\title{
Seaweed Supplementation Failed to Affect Fecal Microbiota and Metabolome as Well as Fecal IgA and Apparent Nutrient Digestibility in Adult Dogs
}

\author{
Carlo Pinna ${ }^{1}\left(\mathbb{D}\right.$, Carla Giuditta Vecchiato ${ }^{1}\left(\mathbb{D}\right.$, Monica Grandi ${ }^{1, *}$,, Claudio Stefanelli ${ }^{2}$, Augusta Zannoni ${ }^{1}(\mathbb{D}$ \\ and Giacomo Biagi ${ }^{1}$ \\ 1 Department of Veterinary Medical Sciences, University of Bologna, via Tolara di Sopra 50, \\ 40064 Ozzano Emilia, Italy; carlo.pinna2@unibo.it (C.P.); carla.vecchiato2@unibo.it (C.G.V.); \\ augusta.zannoni@unibo.it (A.Z.); giacomo.biagi@unibo.it (G.B.) \\ 2 Department for Life Quality Studies, University of Bologna, Corso d'Augusto 237, 47921 Rimini, Italy; \\ claudio.stefanelli@unibo.it \\ * Correspondence: monica.grandi8@unibo.it
}

Citation: Pinna, C.; Vecchiato, C.G.; Grandi, M.; Stefanelli, C.; Zannoni, A.; Biagi, G. Seaweed Supplementation Failed to Affect Fecal Microbiota and Metabolome as Well as Fecal IgA and Apparent Nutrient Digestibility in Adult Dogs. Animals 2021, 11, 2234. https://doi.org/10.3390/ani11082234

Academic Editor: W. Jean Dodds

Received: 23 June 2021

Accepted: 28 July 2021

Published: 29 July 2021

Publisher's Note: MDPI stays neutral with regard to jurisdictional claims in published maps and institutional affiliations.

Copyright: (c) 2021 by the authors. Licensee MDPI, Basel, Switzerland. This article is an open access article distributed under the terms and conditions of the Creative Commons Attribution (CC BY) license (https:/ / creativecommons.org/licenses/by/ $4.0 /)$.
Simple Summary: Seaweeds represent a source of bioactive compounds that have recently drawn the attention of the scientific community for their possible application as health-promoting ingredients. In particular, their indigestible polysaccharides have exhibited promising prebiotic properties both in humans and in farm animals. The present study investigated for the first time in healthy adult dogs the effects of dietary supplementations with intact seaweeds (brown algae Ascophyllum nodosum, Undaria pinnatifida, Saccharina japonica and red alga Palmaria palmata) on some fecal bacterial populations and metabolites, fecal IgA and apparent total tract digestibility of nutrients. The different algal supplementations (fed to ten healthy adult dogs at a dietary dose of $15 \mathrm{~g} / \mathrm{kg}$ for 28 days) did not have any significant effect on the selected fecal microbial parameters, intestinal immunity and nutrient digestibility. Further studies investigating higher dietary inclusions of intact seaweeds or their polysaccharide extracts are needed to gain a better understanding of the potential of these interesting marine resources in companion animal nutrition.

Abstract: The present study investigated in dogs the dietary effects of intact seaweeds on some fecal bacterial populations and metabolites, fecal IgA and apparent total tract digestibility (ATTD). Ten healthy adult dogs were enrolled in a $5 \times 5$ replicated Latin square design to evaluate five dietary treatments: control diet (CD); CD + Ascophyllum nodosum; CD + Undaria pinnatifida; CD + Saccharina japonica; $\mathrm{CD}+$ Palmaria palmata ( $n$ replicates per treatment $=10$ ). Seaweeds were added to food at a daily dose of $15 \mathrm{~g} / \mathrm{kg}$. The CD contained silica as a digestion marker. Each feeding period lasted $28 \mathrm{~d}$, with a $7 \mathrm{~d}$ wash-out in between. Feces were collected at days 21 and 28 of each period for chemical and microbiological analyses. Fecal samples were collected during the last five days of each period for ATTD assessment. Dogs showed good health conditions throughout the study. The fecal chemical parameters, fecal IgA and nutrient ATTD were not influenced by algal supplementation. Similarly, microbiological analyses did not reveal any effect by seaweed ingestion. In conclusion, algal supplementation at a dose of $15 \mathrm{~g} / \mathrm{kg}$ of diet failed to exert noticeable effects on the canine fecal parameters evaluated in the present study.

Keywords: marine macroalgae; prebiotics; immunomodulation

\section{Introduction}

The crucial role that the intestinal microbiota plays in supporting host health is a wellestablished concept [1] and in recent decades scientific research has widely investigated different nutritional strategies aimed to positively influence the microbial ecosystem of the gastrointestinal tract [2]. Among the several dietary components investigated in this 
context, in particular, undigestible carbohydrates (i.e., oligosaccharides) have been explored both in humans $[3,4]$ and other animal species such as dogs [5,6], mostly for their potential benefits on the composition and activity of the gut microbiota, leading the way to the nutritional "prebiotic" approach aimed to maintain or improve host health [7].

In this context, marine macroalgae (seaweeds), plant-like multi-cellular organisms representing a substantial part of the ocean biomass and a traditional food for some Asian human populations, have recently drawn the attention of the scientific community for their possible application as health-promoting ingredients both in human diets [8] and animal feeds [9]. Seaweeds, in fact, represent an interesting source of undigestible polysaccharides, bioactive compounds (including polyphenols, fatty acids and carotenoids) and, in some cases, proteins. Moreover, due to this last characteristic, they have been proposed as encouraging sustainable alternatives to conventional animal feed resources, particularly in the aquaculture sector [10].

Macroalgae comprise thousands of species that are classified as brown (Phaeophyta), red (Rhodophyta) and green (Chlorophyta) algae according to their pigmentation. Their major components are minerals [11] and a fiber fraction [12]. The latter mainly consists of undigestible polysaccharides (e.g., alginate, laminarins and fucoidans in brown algae; carrageenans and agar in red algae; ulvans in green algae) that have recently attracted scientific interest due to their biological properties such as antitumor, antiadhesive, antioxidant, antitoxin, immunomodulatory and anti-infection effects [13]. Moreover, these last components, providing resistance to gastric acidity and host digestive processes, appear promising as prebiotic substrates [14]. In this regard, several in vitro and in vivo studies investigating the prebiotic potential of intact seaweeds or their polysaccharide extracts have been published in recent years [15-17].

In monogastric farm animals like pigs, broilers and fish, some interesting positive effects on intestinal microbiota and the local immune system, in particular of intact brown seaweeds and their extracts, have been described $[10,18,19]$. Conversely, concerning companion animals such as dogs and cats, studies are rather limited and mainly focused on the evaluation of the effect of some algal polysaccharides commonly used as gelling agents in wet pet food, such as alginate [20] and carrageenan [21], on apparent nutrient digestibility. Furthermore, some studies investigating the efficacy of Ascophyllum nodosum in maintaining oral health [22,23] and in preserving palatability [24] have been published in recent years. On the other hand, to the authors' knowledge, studies evaluating the effects of seaweeds on the intestinal environment in dogs and cats are have not be carried out.

The aim of the present study was to evaluate the effects deriving from dietary supplementations with different intact brown seaweeds (Ascophyllum nodosum (AN), Undaria pinnatifida (UP) and Saccharina japonica (SJ)) or one intact red seaweed (Palmaria palmata $(P P))$ on some fecal microbial populations and metabolites, fecal IgA and apparent total tract digestibility (ATTD) of nutrients in healthy adult dogs. We supposed that these intestinal functionality-associated parameters would be positively influenced by algal supplementation.

\section{Materials and Methods}

\subsection{Animals and Diets}

Ten healthy household adult dogs were involved in the study. They were between 1 and 6 years of age, of different breeds (five small to medium-sized cross-breed dogs, three Border Collies, one Australian Shepherd and one Labrador Retriever). Concerning gender and reproductive status, there were eight spayed females, one castrated male and one intact male. Their average body weight \pm standard deviation was $22.8 \pm 6.1 \mathrm{~kg}$. Their median body condition score was 4.5 (range from 4 to 5), according to the 9-point scale proposed by Laflamme et al. [25]. During the trial, dogs remained in their usual environment. All the dogs were regularly vaccinated and periodically treated for intestinal parasites; dogs did not display gastrointestinal signs during the previous year. Owners were asked to monitor the feeding behavior, the maintenance of body weight and the stool appearance and consistency of their dog and to report any change occurring during the study. 
One commercial extruded and complete diet formulated for adult dogs (Effeffe Pet Food S.p.A., Padua, Italy), containing dehydrated poultry protein, rice, maize, wheat, animal fats, fish meal, linseed, sunflower oil, dehydrated eggs, sodium, phosphate, potassium chloride and sodium chloride, was used as the control diet (CD) for the study. Four different experimental diets were set up, through the supplementation of the CD with four intact seaweeds products. In particular, it was decided to use three brown seaweeds: AN, UP and SJ, and one red seaweed: PP. In order to remove any contaminants, the algae were washed with tap water and rinsed twice with deionized water. Finally, algae were freeze-dried and ground through a $1 \mathrm{~mm}$ screen. The algal supplements were added at a concentration of $15 \mathrm{~g} / \mathrm{kg}$ of as-is diet. Since the seaweeds were in form of a powder, they were spread over the kibble together with a small amount of water to ensure their adhesion and total consumption. Dogs were fed twice a day. Consequently, the daily dose of supplements was divided and added equally to each of the two planned daily meals. No snack or other food was offered to the dogs during the whole study period. The CD did not include significant amounts of soluble fiber sources. Silica was included at a dose of $5 \mathrm{~g} / \mathrm{kg}$ as a source of acid-insoluble ash to be used as digestion marker. The dogs' daily ration was set up by considering the energy content of the CD (determined through the modified Atwater conversion factors) and the daily energy requirements, according to the recommendations for the maintenance of adult dogs with a moderate activity level: $120 \mathrm{kcal} / \mathrm{kg}$ $\mathrm{BW}^{0.75}$ [26]. Prior to the beginning of the study, the determination of critical trace elements and potentially dangerous metals was performed to check their concentration in the four intact seaweeds. The chemical analysis of the CD and the algal supplements is reported in Table 1.

\subsection{Experimental Design and Sample Collection}

The feeding trial was planned as a $5 \times 5$ replicated Latin square design. At the beginning of the study, all dogs were adapted to the basal diet for 30 days. During the crossover study, groups of two dogs received each of the five dietary treatments (CD and the four seaweed-supplemented diets). Each feeding period lasted 28 days, with a 7-day wash-out in between periods during which all dogs received the CD. On days 21 and 28 of each feeding period, a fresh fecal sample was collected within $30 \mathrm{~min}$ of defecation and then frozen at $-80{ }^{\circ} \mathrm{C}$ for chemical (dry matter (DM), ammonia, short-chain fatty acids (SCFAs), branched-chain fatty acids (BCFAs) and biogenic amines) and microbiological analyses. A sub-sample of feces collected at both time-points (day 21 and 28) was freeze-dried for IgA measurement. During the last five days of each feeding period (from day 24 to 28), fecal samples were pooled and frozen at $-20^{\circ} \mathrm{C}$ and successively freeze-dried for nutrient analyses and apparent total tract digestibility assessment.

\subsection{Chemical Analyses and ATTD Assessment}

The nutrients in the CD, intact seaweeds and freeze-dried fecal samples collected during the last 5 days of each feeding period were quantified according to AOAC International standard methods [27] (method 954.01 for crude protein, method 942.05 for crude ash, method 965.17 for phosphorus; only in CD and seaweeds: method 950.46 for water, method 920.39 for ether extract, method 991.43 for total, soluble and insoluble fiber and method 962.09 for crude fiber). Acid-insoluble ash was determined according to Vogtmann et al. [28]. For the determination of macrominerals $\mathrm{Ca}, \mathrm{Na}, \mathrm{Mg}$ and $\mathrm{K}$ and trace elements $\mathrm{Zn}, \mathrm{Mn}, \mathrm{Fe}$ and $\mathrm{Cu}$, ash samples of the CD, algal supplements and freeze-dried feces were analyzed by atomic absorption spectrometry according to an International Standards method (EN ISO 6869:2000) [29]. Metal and other trace element (Se, As and $\mathrm{Sb}$ ) assessment in seaweeds was performed through inductively coupled plasma-mass spectrometry (ICP-MS), following the method described by Carpenè et al. [30]. 
Table 1. Chemical composition of the commercial extruded control diet (CD) and intact seaweeds used as supplements ( $15 \mathrm{~g} / \mathrm{kg}$ of as-is diet) during the present study.

\begin{tabular}{|c|c|c|c|c|c|}
\hline & CD & $\begin{array}{c}\text { Ascophyllum } \\
\text { Nodosum }\end{array}$ & $\begin{array}{l}\text { Palmaria } \\
\text { Palmata }\end{array}$ & $\begin{array}{c}\text { Undaria } \\
\text { Pinnatifida }\end{array}$ & $\begin{array}{c}\text { Saccharina } \\
\text { Japonica }\end{array}$ \\
\hline Dry matter $(\mathrm{g} / \mathrm{kg})$ & 939 & 910 & 876 & 795 & 831 \\
\hline \multicolumn{6}{|c|}{ On a dry matter basis $(\mathrm{g} / \mathrm{kg})$} \\
\hline Crude protein & 271 & 51.4 & 142 & 126 & 117 \\
\hline Ether extract & 164 & 33.5 & 0.77 & 2.65 & 2.83 \\
\hline Crude fiber & 16.2 & 34.6 & 25.6 & 42.5 & 74.7 \\
\hline Insoluble dietary fiber & 59.2 & 392.7 & 180.4 & 275.1 & 435.5 \\
\hline Soluble dietary fiber & 18.2 & 156.4 & 167.5 & 53.8 & 115.7 \\
\hline Total dietary fiber & 77.4 & 549.1 & 347.9 & 328.9 & 551.2 \\
\hline Crude ash & 70.2 & 212 & 291 & 385 & 217 \\
\hline Acid-insoluble ash & 5.37 & 2.19 & 1.09 & 0.49 & 0.30 \\
\hline \multicolumn{6}{|l|}{ Macrominerals $(\mathrm{g} / \mathrm{kg})$} \\
\hline $\mathrm{Ca}$ & 0.175 & 0.215 & 0.058 & 0.104 & 0.169 \\
\hline$P$ & 0.085 & 0.005 & 0.019 & 0.032 & 0.010 \\
\hline$M g$ & 0.011 & 0.080 & 0.039 & 0.115 & 0.088 \\
\hline $\mathrm{Na}$ & 0.050 & 0.384 & 0.292 & 0.760 & 0.278 \\
\hline$K$ & 0.030 & 0.088 & 0.470 & 0.386 & 0.224 \\
\hline \multicolumn{6}{|l|}{ Trace minerals (mg/kg) } \\
\hline $\mathrm{Zn}$ & 166.3 & 46.3 & 18.1 & 25.7 & 57.5 \\
\hline$M n$ & 42.6 & 12.3 & 58.6 & 5.77 & 4.68 \\
\hline $\mathrm{Fe}$ & 158.5 & 161.1 & 249.9 & 133.7 & 54.4 \\
\hline $\mathrm{Cu}$ & 12.9 & n.q. & n.q. & n.q. & n.q. \\
\hline \multicolumn{6}{|c|}{$\begin{array}{l}\text { Metals and other trace elements } \\
\qquad(\mathrm{mg} / \mathrm{kg})\end{array}$} \\
\hline $\mathrm{Pb}$ & & 0.078 & 1.98 & 0.47 & 0.23 \\
\hline$C d$ & & 0.30 & 0.05 & 0.22 & 0.20 \\
\hline $\mathrm{Cr}$ & & 0.61 & 1.16 & 0.24 & 0.29 \\
\hline $\mathrm{Hg}$ & & 0.02 & 0.02 & 0.02 & 0.03 \\
\hline As & & 33.8 & 3.84 & 36.1 & 24.2 \\
\hline$A l$ & & 27.0 & 322 & 33.1 & 23.8 \\
\hline Co & & 0.43 & 0.30 & 0.18 & 0.08 \\
\hline $\mathrm{Ni}$ & & 1.08 & 1.96 & 2.03 & 0.21 \\
\hline Se & & 0.06 & 0.18 & 0.21 & 0.08 \\
\hline Mo & & 0.84 & 0.64 & 0.29 & 0.17 \\
\hline$A g$ & & 0.05 & 0.20 & 0.01 & 0.01 \\
\hline$T i$ & & n.q. & 0.01 & n.q. & n.q. \\
\hline$U$ & & 0.62 & 0.10 & 0.51 & 0.45 \\
\hline$S b$ & & 0.08 & 0.03 & 0.03 & 0.03 \\
\hline$V$ & & 1.25 & 12.7 & 0.41 & 2.43 \\
\hline
\end{tabular}

n.q.: not quantified.

Apparent total tract DM digestibility of the experimental diets was measured through the following equation:

$$
100-[(100 \times \% \text { marker in the diet }) / \% \text { marker in feces }]
$$

Apparent total tract digestibility of each nutrient was established through the following equation:

$100-[\%$ nutrient in feces $\times(100-\%$ DM digestibility $) / \%$ nutrient in the diet $]$

Since the seaweed-based supplements contained a certain amount of nutrients (ash and silica, in particular, and proteins), in order to accurately calculate the ATTD coefficients, the nutrient percentage in the diet was calculated by considering both the contribution of the $\mathrm{CD}$ and the seaweed supplements.

Fecal $\mathrm{pH}$ was evaluated with a SevenMulti $\mathrm{pH}$ meter (Mettler Toledo, Milano, Italy) in diluted fecal samples (1:10 $w / v$ in distilled water). Ammonia was quantified through a commercial kit (Urea/BUN-Color; BioSystems S.A., Barcelona, Spain). SCFAs and BCFAs were determined using a $2 \mathrm{~m}$ glass column (inner diameter, $3 \mathrm{~mm}$ ) of $10 \% \mathrm{SP}-1000+1 \% \mathrm{H}_{3} \mathrm{PO}_{4}$ on 100/120 Chromosorb W AW with nitrogen as the carrier. The chromatograph was a 
Fisons HRGC MEGA 2 series 8560 with a flame ionization detector. Both the injector and detector temperatures were $200{ }^{\circ} \mathrm{C}$, and the oven was $155^{\circ} \mathrm{C}$. 2-ethylbutyric acid was used as the internal standard. For the measurement of biogenic amines, feces were diluted 1:5 w/ $v$ with perchloric acid (0.3 M); biogenic amines were later separated by HPLC and enumerated through fluorimetry, as described by Stefanelli et al. [31].

\subsection{Microbial Analyses}

Bacterial genomic DNA was extracted and isolated from fecal samples ( 200 mg) using the Norgen Stool DNA Isolation Kit (Norgen Biotek Corp., Thorold, ON, Canada). Isolated DNA concentration (ng/ $\mu \mathrm{L}$ ) and purity were measured using a DeNovix DS-11 spectrophotometer (DeNovix Inc., Wilmington, DE, USA). Template DNA was diluted to $50 \mathrm{ng} / \mu \mathrm{L}$ and stored at $-20{ }^{\circ} \mathrm{C}$ until further analysis. Total bacteria [32], Firmicutes [33], Bifidobacterium spp., Enterococcus spp. [34], Lactobacillus spp. [35], Clostridium cluster I [36], Escherichia coli [37] and Faecalibacterium prausnitzii [38], were quantified via quantitative polymerase chain reaction (qPCR) using specific primers (Table 2).

Table 2. Primers used for quantitative PCR analysis.

\begin{tabular}{|c|c|c|c|}
\hline $\begin{array}{l}\text { Target Bacterial } \\
\text { Populations }\end{array}$ & Primers & Sequence $\left(5^{\prime}-3^{\prime}\right)$ & Reference \\
\hline Total bacteria & $\begin{array}{l}\text { UniF } \\
\text { UniR }\end{array}$ & $\begin{array}{l}\text { CCTACGGGAGGCAGCAG } \\
\text { ATTACCGCGGCTGCTGG }\end{array}$ & [32] \\
\hline Firmicutes & $\begin{array}{l}\text { Firm350f } \\
\text { Firm814r }\end{array}$ & $\begin{array}{l}\text { GGCAGCAGTRGGGAATCTTC } \\
\text { ACACYTAGYACTCATCGTTT }\end{array}$ & [33] \\
\hline Bifidobacterium spp. & $\begin{array}{l}\text { Bif_F } \\
\text { Bif_R }\end{array}$ & $\begin{array}{l}\text { TCGCGTCYGGTGTGAAAG } \\
\text { CCACATCCAGCRTCCAC }\end{array}$ & [34] \\
\hline Enterococcus spp. & $\begin{array}{l}\text { Ent_F } \\
\text { Ent_R }\end{array}$ & $\begin{array}{l}\text { CCCTTATTGTTAGTTGCCATCATT } \\
\text { ACTCGTTGTACTTCCCATTGT }\end{array}$ & [34] \\
\hline Lactobacillus spp. & $\begin{array}{l}\text { Lac_F } \\
\text { Lac_R }\end{array}$ & $\begin{array}{c}\text { AGCAGTAGGGAATCTTCCA } \\
\text { CACCGCTACACATGGAG }\end{array}$ & {$[35]$} \\
\hline Clostridium cluster I & $\begin{array}{l}\text { CloI-F } \\
\text { CloI-R }\end{array}$ & $\begin{array}{l}\text { TACCHRAGGAGGAAGCCAC } \\
\text { GTTCTTCCTAATCTCTACGCAT }\end{array}$ & [36] \\
\hline Escherichia coli & $\begin{array}{l}\text { Coli_F } \\
\text { Coli_R }\end{array}$ & $\begin{array}{l}\text { GTTAATACCTTTGCTCATTGA } \\
\text { ACCAGGGTATCTAATCCTGTT }\end{array}$ & {$[37]$} \\
\hline Faecalibacterium prausnitzii & $\begin{array}{l}\text { Fprau } 07 \\
\text { Fprau } 02\end{array}$ & $\begin{array}{l}\text { CCATGAATTGCCTTCAAAACTGTT } \\
\text { GAGCCTCAGCGTCAGTTGGT }\end{array}$ & [38] \\
\hline
\end{tabular}

The qPCR assay was performed using a CFX96 Touch thermal cycler (Bio-Rad, Hercules, CA, USA).

Amplification was performed in duplicate for each bacterial group within each sample, while standard curves were run in triplicate.

Briefly, the PCR reaction contained 7.5 $\mu \mathrm{L} 2 \times$ SensiFAST No-ROX PCR MasterMix (Bioline $\mathrm{GmbH}$, Luckenwalde, Germany), $4.8 \mu \mathrm{L}$ of nuclease-free water, $0.6 \mu \mathrm{L}$ of each 10 pmol primer and $1.5 \mu \mathrm{L}$ of template DNA for a final reaction volume of $15 \mu \mathrm{L}$. The amplification cycle was as follows: initial denaturation at $95{ }^{\circ} \mathrm{C}$ for $3 \mathrm{~min}, 95{ }^{\circ} \mathrm{C}$ for $5 \mathrm{~s}$, primer annealing at $55-64{ }^{\circ} \mathrm{C}$ for $10 \mathrm{~s}$ and $72{ }^{\circ} \mathrm{C}$ for $8 \mathrm{~s}$. The cycle was repeated 40 times. A negative control (without the DNA template) was also run for each primer pair. Standard curves were constructed from eight tenfold dilutions for total bacteria, Firmicutes, bifidobacteria, enterococci, lactobacilli, Clostridium cluster I, Escherichia coli and Faecalibacterium prausnitzii. Cycle threshold values were plotted against standard curves for the quantification of the target bacterial DNA. Melting curves were checked after amplification to ensure the single product amplification of a consistent melting temperature. 


\subsection{Fecal IgA Determination}

The determination of IgA content in lyophilized fecal samples was carried out by using a commercial kit (dog IgA ELISA Quantitation Set, Bethyl Laboratories Inc., Montgomery, TX, USA; assay range: $15.6-1000 \mathrm{ng} / \mathrm{mL}$ ), following the procedure described by Zannoni et al. [39].

\subsection{Statistical Analyses}

Firstly, for each parameter, data measured after days 21 and 28 of each feeding period were compared by a Student's $t$-test. Since no significant difference was observed, mean values obtained from each dog at 21 and $28 \mathrm{~d}$ were considered for statistical analysis. Data were assessed for normality through a D'Agostino and Pearson omnibus normality test. When they were not normally distributed, a logarithmic transformation was applied to normalize the data distribution. Normalized data were analyzed by a general linear model with diet as a fixed effect and animal and period as random effects. The Dunnett test was used as the post-test. When microbiological analysis revealed unquantifiable outcomes, "zero" values were assigned.

Levels of significance and tendency were set at $p \leq 0.05$ and $0.05<p<0.1$, respectively. Statistical analyses were performed using Statistica 10.0 software (Stat Soft Italia, Padua, Italy).

\section{Results}

Dog owners did not report any modification in body weight or fecal appearance and consistency of their animals during the study. All the dogs maintained good health conditions throughout the trial and entirely consumed the assigned daily ration and the algal supplements.

The chemical parameters evaluated in fecal samples did not show any influence by the dietary supplementation with intact seaweeds (Table 3).

Table 3. Fecal dry matter (DM) percentage and concentrations of fecal ammonia, SCFAs, BCFAs $(\mu \mathrm{mol} / \mathrm{g}$ fecal DM) and biogenic amines (nmol/g fecal DM) in dogs fed with a control diet supplemented or not with different intact seaweeds.

\begin{tabular}{cccccccc}
\hline Chemical Parameters & CD & AN & PP & UP & SJ & $p$-Value & $\begin{array}{c}\text { Pooled } \\
\text { SEM }\end{array}$ \\
\hline DM & 40.6 & 39.6 & 40.2 & 41.2 & 40.1 & 0.984 & 1.5 \\
Ammonia & 71.0 & 71.7 & 76.6 & 72.7 & 79.6 & 0.887 & 6.5 \\
\hline Acetic acid $^{\circ}$ & 125 & 131 & 144 & 129 & 149 & 0.562 & 11.6 \\
Propionic acid $^{\circ}$ & 85.9 & 99.3 & 88.1 & 78.4 & 91.3 & 0.738 & 9.5 \\
n-Butyric acid $^{\circ}$ & 20.7 & 25.1 & 24.6 & 25.1 & 30.5 & 0.271 & 2.9 \\
Valeric acid $^{\circ}$ & 0.47 & 0.16 & 1.21 & 0.67 & 0.45 & 0.414 & 0.36 \\
iso-Butyric acid $^{\circ}$ & 4.21 & 4.27 & 4.62 & 4.66 & 4.75 & 0.958 & 0.45 \\
iso-Valeric acid $^{\circ}$ & 5.70 & 6.33 & 6.22 & 6.41 & 6.54 & 0.968 & 0.69 \\
Total SCFA $^{\circ}$ & 231 & 255 & 257 & 233 & 271 & 0.676 & 21.6 \\
Total BCFA $^{\circ}$ & 9.91 & 10.6 & 10.8 & 11.1 & 11.3 & 0.974 & 1.13 \\
SCFA + BCFA $^{\circ}$ & 242 & 266 & 269 & 244 & 282 & 0.668 & 21.8 \\
\hline Putrescine $^{\circ}$ & 3155 & 4398 & 2751 & 3269 & 3554 & 0.634 & 736 \\
Cadaverine $^{\circ}$ & 1215 & 1423 & 1233 & 1772 & 1481 & 0.971 & 454 \\
Spermidine $^{\circ}$ & 1249 & 1049 & 1206 & 1221 & 1256 & 0.832 & 136 \\
Spermine $^{\circ}$ & 700 & 613 & 653 & 592 & 705 & 0.840 & 79.8 \\
\hline
\end{tabular}

Values are the means of 10 dogs per treatment. CD, control diet; AN, control diet supplemented with Ascophyllum nodosum; PP, control diet supplemented with Palmaria palmata; UP, control diet supplemented with Undaria pinnatifida; SJ, control diet supplemented with Saccharina japonica. ${ }^{\circ}$ GLM analysis performed after logarithmic transformation to normalize data.

The microbial populations evaluated in the present study were not significantly affected by treatments (Table 4). Concerning ATTD coefficients, seaweeds did not influence 
the digestibility of the macronutrients and most of the minerals evaluated. Only Ca digestibility showed a tendency to be influenced by algal supplementation $(p=0.07)$. In particular, compared with the CD, ATTD of Ca was improved when dogs received the AN $\operatorname{diet}(61.8 \%$ vs. $40.1 \% ; p=0.03)$ (Table 5$)$.

Table 4. Microbial analysis (log copies DNA/ng DNA) of feces from dogs fed with a control diet supplemented or not with different intact seaweeds.

\begin{tabular}{cccccccc}
\hline $\begin{array}{c}\text { Bacterial Populations } \\
\text { Item }\end{array}$ & CD & AN & PP & UP & SJ & $p$-Value & Pooled SEM \\
\hline Total bacteria & 5.92 & 5.91 & 6.16 & 6.29 & 6.18 & 0.614 & 0.17 \\
$\quad \begin{array}{c}\text { Firmicutes } \\
\text { Bifidobacterium spp. }\end{array}$ & 2.87 & 2.62 & 2.79 & 2.68 & 3.00 & 0.807 & 0.24 \\
Lactobacillus spp. & 0.30 & 0.26 & 0.19 & 0.44 & 0.46 & 0.852 & 0.18 \\
Faecalibacterium prausnitzii & n.q. & n.q. & 0.08 & 0.02 & 0.20 & 0.190 & 0.07 \\
Enterococcus spp. & 1.20 & 0.75 & 0.96 & 0.65 & 0.98 & 0.178 & 0.16 \\
Clostridium cluster I & 4.01 & 3.91 & 4.13 & 4.60 & 4.44 & 0.308 & 0.23 \\
E. coli & 2.49 & 2.72 & 2.85 & 2.79 & 2.67 & 0.587 & 0.14 \\
\hline
\end{tabular}

Values are the means of 10 dogs per treatment. CD, control diet; AN, control diet supplemented with Ascophyllum nodosum; PP, control diet supplemented with Palmaria palmata; UP, control diet supplemented with Undaria pinnatifida; SJ, control diet supplemented with Saccharina japonica; n.q., not quantified.

Table 5. Apparent total tract digestibility coefficients in dogs fed with a control diet supplemented or not with different intact seaweeds.

\begin{tabular}{cccccccc}
\hline Nutrients Item & CD & AN & PP & UP & SJ & $p$-Value & $\begin{array}{c}\text { Pooled } \\
\text { SEM }\end{array}$ \\
\hline $\begin{array}{c}\text { Dry matter } \\
\text { Crude protein }\end{array}$ & 87.7 & 90.2 & 89.9 & 90.5 & 89.7 & 0.568 & 1.2 \\
Crude ash & 50.1 & 65.2 & 61.5 & 63.9 & 60.5 & 0.218 & 4.6 \\
Macrominerals & & & & & & & \\
Ca & 40.1 & $61.8 *$ & 58.3 & 50.3 & 57.1 & $\mathbf{0 . 0 7 3}$ & 5.32 \\
P & 39.5 & 52.5 & 55.8 & 50.0 & 51.7 & 0.512 & 6.36 \\
Mg & 41.0 & 42.6 & 30.0 & 31.7 & 38.8 & 0.916 & 10.5 \\
Na & 96.4 & 97.3 & 98.1 & 97.9 & 97.4 & 0.108 & 0.41 \\
\hline K & 95.7 & 95.4 & 94.8 & 94.7 & 95.5 & 0.749 & 0.63 \\
Trace minerals & & & & & & & \\
$\mathrm{Zn}$ & 16.7 & 39.6 & 35.4 & 32.8 & 35.6 & 0.406 & 8.42 \\
$\mathrm{Mn}$ & 12.8 & 34.0 & 33.9 & 25.2 & 30.1 & 0.420 & 8.33 \\
$\mathrm{Fe}$ & -2.41 & 16.6 & 0.67 & 7.49 & 14.7 & 0.276 & 7.20 \\
$\mathrm{Cu}$ & 53.2 & 59.2 & 57.0 & 54.8 & 61.4 & 0.840 & 5.45 \\
\hline
\end{tabular}

Values are the means of 10 dogs per treatment. CD, control diet; AN, control diet supplemented with Ascophyllum nodosum; PP, control diet supplemented with Palmaria palmata; UP, control diet supplemented with Undaria pinnatifida; SJ, control diet supplemented with Saccharina japonica. ${ }^{*}$ Significantly different from $\mathrm{CD}(p<0.05) .{ }^{\circ}$ GLM analysis performed after logarithmic transformation to normalize data.

Moreover, the concentration of fecal IgA did not significantly change among dietary treatments (Figure 1). 


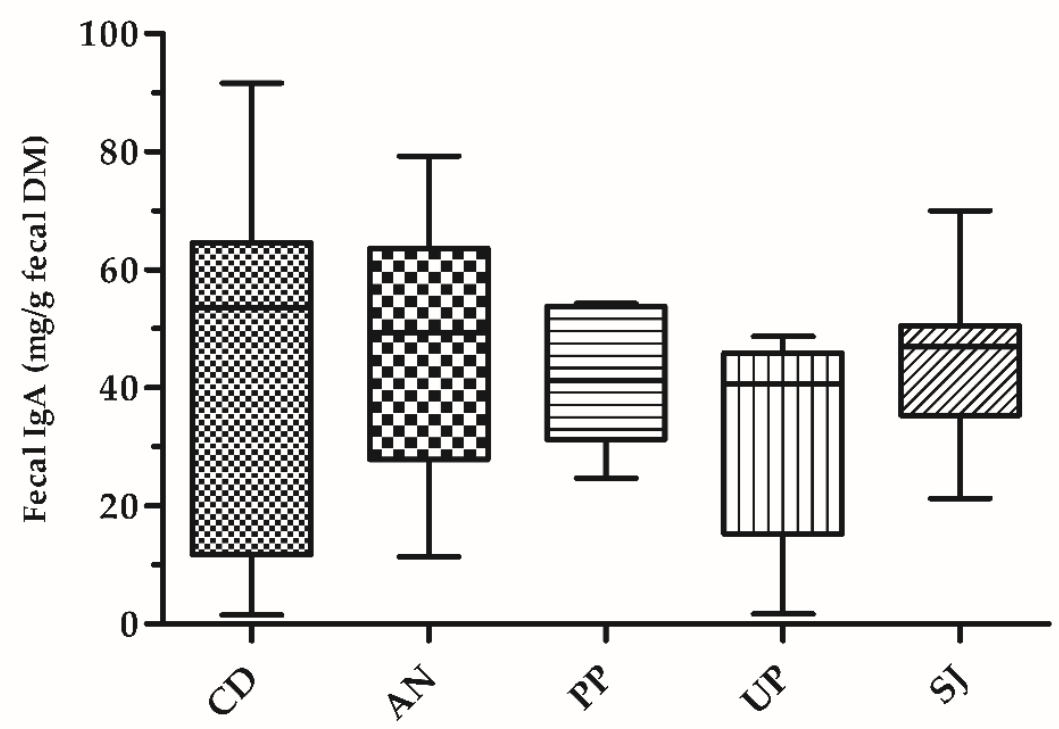

Figure 1. Fecal IgA concentrations (mg/g fecal DM) in dogs fed with a control diet supplemented or not with different intact seaweeds. Values are the means of $10 \mathrm{dogs}$ per treatment. CD, control diet; AN, control diet supplemented with Ascophyllum nodosum; PP, control diet supplemented with Palmaria palmata; UP, control diet supplemented with Undaria pinnatifida; SJ, control diet supplemented with Saccharina japonica.

\section{Discussion}

The purpose of this study was to investigate the effect of dietary supplementations with intact seaweed-based products on the gastrointestinal environment of adult dogs through the determination of ATTD, fecal IgA and selected fecal bacterial populations and metabolites.

In general, the results revealed a negligible influence exerted by the selected seaweeds on canine fecal microbiota. In particular, the lack of significant effects on bacterial metabolites such as SCFAs, BCFAs and biogenic amines reflected the absence of modulation in the microbial populations evaluated in fecal samples.

Differently from the present study, several literature reviews, describing the results of both in vitro and in vivo studies, have recently emphasized interesting prebiotic effects deriving from dietary supplementation with intact seaweeds (such as Saccharina, Laminaria, Ascophyllum and Undaria spp.) or their major undigestible polysaccharide components (namely, alginate, fucoidan and laminarin extracted from brown algae) [12,16-18].

Recently, a growing interest in the potential application of marine macroalgae or their extracts in farm animal nutrition has been observed. In pigs, for example, brown algae are considered promising dietary supplements (and safe alternatives to antibiotic growth promoters), able to exert prebiotic and immunomodulatory effects on the intestinal environment $[19,40]$. In fact, differently from the present study, previous investigations in weaning or weaned piglets fed seaweed extracts such as laminarins $(0.3 \mathrm{~g} / \mathrm{kg})$ and fucoidans $(0.24 \mathrm{~g} / \mathrm{kg})$ from the brown algae AN and Laminaria spp. have shown positive changes in the intestinal microbiota, such as increased Lactobacillus and Bifidobacterium spp., decreased Enterobacteria, higher concentration of SCFAs, acidification of the $\mathrm{pH}$ and/or a reduction in ammonia in the hindgut [10]. Moreover, laminarin-rich extracts deriving from AN and Laminaria hyperborean have shown interesting antimicrobial activity against $E$. coli, Salmonella typhimurium, Staphylococcus aureus and Listeria monocytogenes [41]. Likewise, a study by Patra et al. [42] described interesting antibacterial properties exerted by an essential oil extracted from UP on pathogenic Salmonella typhimurium and Staphylcoccus aureus bacterial strains.

Additionally, concerning red seaweeds, both as whole biomass or polysaccharide extracts (i.e., carrageenans and agarans), interesting prebiotic effects on gut microbiota 
have been reported [43,44]. In vitro, dietary fibers extracted from PP (mainly constituted by xylans) have been shown to stimulate microbial fermentation, enhancing SCFA production [45]. In broiler chickens, the consumption of PP at dietary doses of 18, 24 and $30 \mathrm{~g} / \mathrm{kg}$ positively influenced the presence of beneficial intestinal bacteria (in particular, lactobacilli and bifidobacteria) and decreased the number of undesirable microbes like $\mathrm{Cl}$. perfringens [46]. Similarly, feed supplementation with other red seaweeds, Condrus crispus and Sarcodiotheca gaudichaudii (at doses of 5-10 and $20 \mathrm{~g} / \mathrm{kg}$ of diet), positively affected the intestinal environment of layers hens, as higher concentrations of SCFAs and a higher abundance of Bifidobacterium longum and Streptococcus salivarius together with a reduction in C. perfringens was observed [47]. Nevertheless, other studies investigating the effects of polysaccharide extract [48] or intact seaweeds such as A. nodosum at dietary doses up to $10 \mathrm{~g} / \mathrm{kg}$ [49] in pigs failed to demonstrate clear effects on intestinal microbiota, similarly to the present trial.

As previously pointed out by other authors, the inconsistent results from studies on monogastric farm animals receiving seaweeds as "whole products" could be attributable to the different chemical composition of this type of supplements. In particular, their polysaccharide content can greatly differ in relation to algal species and environmental factors (not only season and temperature, but also harvest time and geographical location) [10,50]. In brown algae, the total polysaccharide content has been estimated within a wide range between $10 \%$ and $75 \%$ and in red algae between $10 \%$ and $59 \%$ [15]. The nutritional content of the algal supplements used in the present study (including the concentration of minerals and fibrous fractions) results in agreement with the values reported in the literature $[10,19]$. In this regard, the absence of effects observed in the dogs is difficult to explain. It could be hypothesized that, considering the absence of significant potential prebiotic ingredients in the $\mathrm{CD}$, the amount of undigestible polysaccharides derived from seaweed supplementation reaching the canine hindgut was too small to exert evident modulation on the fecal parameters investigated here in this species.

Moreover, it must be underlined that in the present investigation only few of the main key taxa of the canine microbiome have been evaluated. This might represent a limitation for the study since possible changes in other bacteria could not have been detected.

In general, for ethical reasons, according to the current European legislation, feces represent the only analyzable type of sample in studies investigating the gastrointestinal tract of companion animals. Actually, fecal composition is not fully representative of the gut environment [51], even though this material necessarily contains bacteria and compounds derived from the intestinal tract. In particular, microbial fermentation occurring in the ileum of dogs may not affect colonic and fecal microbiota [52]. This aspect could at least partially explain the lack of effects from algal supplementation observed in the present study. Furthermore, the differences in terms of age, body size and living environment between the dogs might also have contributed to the outcome of this investigation. On the other hand, prebiotic effects from dietary algal substrates have been mostly described by studies carried out with more standardized and conventional "experimental" animals such as pigs and chickens [10,19], where digesta sampling from the ileum or colon is allowed by current legislation.

In this study, fecal IgA analysis revealed no effect in dogs when they received the supplemented diets. Secretory IgA is the most important humoral immune factor in the intestinal tract and represents the expression of the mucosal immune response [53], limiting, in particular, the access of commensal and potentially pathogenic bacteria to the intestinal epithelial surface and neutralizing bacterial toxins [54]. Intestinal IgA has been described to be involved in gut homeostasis maintenance [55] and gut microbiota have been shown to influence its production [56,57]. Consequently, higher fecal IgA after a prebiotic supplementation may be interpreted as an enhancement effect of beneficial bacteria and their products on the intestinal immune system [58]. Accordingly, previous studies investigating prebiotics [59] and probiotics [60] in dogs showed an improvement of intestinal IgA excretion, although the literature offers conflicting results in this regard [61-63]. In the present 
study, an increase in fecal IgA would have been explained as an expression of immune stimulatory activity exerted by seaweed supplementation, similar to previous studies in other animal species, albeit other immunological parameters such as tumor necrosis factor or interleukins have been investigated more often in this context [18,43]. Interestingly, a study by Karimi [46] highlighted that the inclusion of intact PP in broilers' diets (at a dose of $18 \mathrm{~g} / \mathrm{kg}$ ) improved the secretion of IgA together with the best growth performance and taller villus height.

It is important to emphasize that algal polysaccharides (glycans) have differences in their structure in comparison to homologous terrestrial compounds [14]. Even though the catabolism of these complex molecules might potentially favor a prebiotic effect in the gut environment, it has been pointed out that the intestinal microbiota must necessarily express specific enzymes to use these marine substrates as a carbon source for bacterial fermentation [64]. Interestingly, in humans, the ability to express this particular enzymatic activity has been demonstrated to be a consequence of horizontal gene transfer from the marine environment, in particular, through the frequent consumption of seaweeds in the diet [65]. In this regard, scientific research has described important geographical differences in terms of the presence and activity of algal polysaccharide-degrading microbial enzymes. Consequently, not all human gut microbiomes have the same competencies in this regard [8] and in terrestrial domestic animals such as dogs and cats, no information is available.

The algal supplementations investigated in the present study did not influence nutrient ATTD. Only Ca digestibility displayed a tendency to be influenced by seaweeds (without reaching statistical significance), with an improvement of this last parameter when dogs received the AN diet.

Better nutrient digestibility has been associated with a beneficial influence on the gut environment from seaweed consumption. In fact, a positive modulation of intestinal microbiota exerted by these marine substrates, favoring an improvement of the production of trophic metabolites such as SCFAs ( $n$-butyrate, in primis) could promote a better absorptive capacity of the intestinal epithelium [66].

Previous studies evaluating the effects of algal supplementations on ATTD in pigs have reported conflicting evidence [18]. Similar to our results, the ingestion of dried intact AN supplements failed to show an influence on diet digestibility both in weaned piglets [67] and adult pigs [68] (dietary doses of 10-20 and $2.5 \mathrm{~g} / \mathrm{kg}$, respectively). Differently, several trials have described an improvement of apparent digestibility of nutrients such as proteins, fat, minerals, neutral detergent fiber and organic and dry matter in piglets receiving dietary supplementations with variable doses of brown seaweed extracts, mainly laminarins $(0.11-$ $0.3 \mathrm{~g} / \mathrm{kg})$, fucoidans $(0.09-0.24 \mathrm{~g} / \mathrm{kg})$ and their combination [19].

Presumably, the lack of effect on ATTD shown by the present trial could be partially attributable to the relatively low dietary dose of intact seaweeds provided to dogs, as the majority of their daily diet consisted of the same control basal diet (CD) during all five experimental periods. Nevertheless, it must be emphasized that the lack of influence on ATTD could be considered positively since the algal supplementations tested in the present study did not affect the relatively high digestibility of the basal diet.

\section{Conclusions}

The present study showed that the ingestion of intact seaweeds at a dose of $15 \mathrm{~g} / \mathrm{kg}$ of diet was well tolerated by the dogs and it did not alter nutrient ATTD. On the other hand, it failed to exhibit noticeable effects on fecal microbiota and immunological parameters such as fecal IgA.

Despite the scientific evidence supporting a promising role for seaweeds and their extracts as "health-promoting ingredients" in farm animals, there is a limited understanding of the effective ability of canine gut microbiota to ferment algal polysaccharides since, to the authors' knowledge, this research represents the first investigation on the effects of algal supplements on the intestinal ecosystem of the dog. 
Since it has been pointed out that intestinal microbiota must necessarily express specific enzymes to use algal polysaccharides as a carbon source for bacterial fermentation [64] and only a regular seaweed consumption could promote a selective pressure on the intestinal microbiota, favoring algal polysaccharide-fermenting bacteria [69], in companion animals such as dogs, for which dietary supplementation with marine vegetables is unusual, the usefulness of seaweed-based ingredients might appear questionable. Moreover, the ability of seaweed to concentrate heavy metals from seawater potentially represents a serious constraint to their consumption. The modest results observed during the present study might suggest the inability of canine intestinal bacteria to utilize the polysaccharides contained in algal supplements, even though it must be stressed that the microbial analysis applied here did not provide an in-depth investigation of the canine fecal microbiome. Certainly, more comprehensive studies are required to investigate the utilization of higher doses of intact seaweeds or their undigestible polysaccharide extracts in pet nutrition.

Author Contributions: Conceptualization, C.P. and G.B.; methodology, C.P., C.G.V. and G.B.; formal analysis, C.P., C.G.V., A.Z. and C.S.; data curation, C.P.; writing-original draft preparation, M.G.; writing-review and editing, C.P., C.G.V., M.G. and G.B.; supervision, G.B. All authors have read and agreed to the published version of the manuscript.

Funding: This research received no external funding.

Institutional Review Board Statement: The study was carried out according to the Italian legislation implementing the European Council Directive 2010/63 on the protection of animals used for scientific purposes. The experimental protocol was reviewed and approved by the Institutional Ethics Committee on Animal Experimentation of the University of Bologna (protocol ID 899, date of approval: 26 June 2019). Informed consent was obtained from all dog owners prior to the beginning of the study.

Informed Consent Statement: Informed consent was obtained from all dog-owners involved in the study.

Data Availability Statement: Data supporting the findings of this study are available from the corresponding author on request.

Acknowledgments: The authors acknowledge Maddalena Zini and Silvia Marchetti for technical assistance.

Conflicts of Interest: The authors declare no conflict of interest.

\section{References}

1. Tuddenham, S.; Sears, C.L. The intestinal microbiome and health. Curr. Opin. Infect. Dis. 2015, 28, 464-470. [CrossRef] [PubMed]

2. Zhang, N.; Ju, Z.; Zuo, T. Time for food: The impact of diet on gut microbiota and human health. Nutrition 2018, 51, 80-85. [CrossRef] [PubMed]

3. Deehan, E.C.; Duar, R.M.; Armet, A.M.; Perez-Muñoz, M.E.; Jin, M.; Walter, J. Modulation of the Gastrointestinal Microbiome with Nondigestible Fermentable Carbohydrates to Improve Human Health. Microbiol. Spectr. 2017, 5, 5. [CrossRef] [PubMed]

4. Davani-Davari, D.; Negahdaripour, M.; Karimzadeh, I.; Seifan, M.; Mohkam, M.; Masoumi, S.J.; Berenjian, A.; Ghasemi, Y. Prebiotics: Definition, Types, Sources, Mechanisms, and Clinical Applications. Foods 2019, 8, 92. [CrossRef]

5. Pinna, C.; Biagi, G. The Utilisation of Prebiotics and Synbiotics in Dogs. It. J. Anim. Sci. 2014, 13, 169-178. [CrossRef]

6. Redfern, A.; Suchodolski, J.; Jergens, A. Role of the gastrointestinal microbiota in small animal health and disease. Vet. Rec. 2017, 181, 370. [CrossRef]

7. Gibson, G.R.; Hutkins, R.; Sanders, M.E.; Prescott, S.L.; Reimer, R.A.; Salminen, S.J.; Scott, K.; Stanton, C.; Swanson, K.S.; Cani, P.D.; et al. Expert consensus document: The International Scientific Association for Probiotics and Prebiotics (ISAPP) consensus statement on the definition and scope of prebiotics. Rev. Gastroenterol. Hepatol. 2017, 14, 491-502. [CrossRef]

8. Wells, M.L.; Potin, P.; Craigie, J.S.; Raven, J.A.; Merchant, S.S.; Helliwell, K.E.; Smith, A.G.; Camire, M.E.; Brawley, S.H. Algae as nutritional and functional food sources: Revisiting our understanding. J. Appl. Phycol. 2017, 29, 949-982. [CrossRef]

9. Makkar, H.P.S.; Tran, G.; Heuzé, V.; Giger-Reverdin, S.; Lessire, M.; Lebas, F.; Ankers, P. Seaweeds for livestock diets: A review. Anim. Feed Sci. Technol. 2016, 212, 1-17. [CrossRef]

10. Øverland, M.; Mydland, L.T.; Skrede, A. Marine macroalgae as sources of protein and bioactive compounds in feed for monogastric animals. J. Sci. Food Agric. 2019, 99, 13-24. [CrossRef]

11. Cabrita, A.R.J.; Maia, M.R.G.; Oliveira, H.M.; Sousa-Pinto, I.; Almeida, A.A.; Pinto, E.; Fonseca, A.J.M. Tracing seaweeds as mineral sources for farm-animals. J. Appl. Phycol. 2016, 28, 3135-3150. [CrossRef] 
12. de Jesus Raposo, M.F.; de Morais, A.M.; de Morais, R.M. Emergent Sources of Prebiotics: Seaweeds and Microalgae. Mar. Drugs 2016, 14, 27. [CrossRef]

13. Xu, S.Y.; Huang, X.; Cheong, K.L. Recent Advances in Marine Algae Polysaccharides: Isolation, Structure, and Activities. Mar. Drugs 2017, 15, 388. [CrossRef] [PubMed]

14. O'Sullivan, L.; Murphy, B.; McLoughlin, P.; Duggan, P.; Lawlor, P.G.; Hughes, H.; Gardiner, G.E. Prebiotics from marine macroalgae for human and animal health applications. Mar. Drugs 2010, 8, 2038-2064. [CrossRef] [PubMed]

15. Sardari, R.R.R.; Nordberg Karlsson, E. Marine Poly- and Oligosaccharides as Prebiotics. J. Agric. Food Chem. 2018, 66, 11544-11549. [CrossRef]

16. Cherry, P.; Yadav, S.; Strain, C.R.; Allsopp, P.J.; McSorley, E.M.; Ross, R.P.; Stanton, C. Prebiotics from Seaweeds: An Ocean of Opportunity? Mar. Drugs 2019, 17, 327. [CrossRef]

17. Gotteland, M.; Riveros, K.; Gasaly, N.; Carcamo, C.; Magne, F.; Liabeuf, G.; Beattie, A.; Rosenfeld, S. The Pros and Cons of Using Algal Polysaccharides as Prebiotics. Front. Nutr. 2020, 7, 163. [CrossRef]

18. Okolie, C.L.; Rajendran, S.R.C.K.; Udenigwe, C.C.; Aryee, A.N.A.; Mason, B. Prospects of brown seaweed polysaccharides (BSP) as prebiotics and potential immunomodulators. J. Food Biochem. 2017, 41, e12392. [CrossRef]

19. Corino, C.; Modina, S.C.; Di Giancamillo, A.; Chiapparini, S.; Rossi, R. Seaweeds in Pig Nutrition. Animals 2019, 9, 1126. [CrossRef]

20. Murray, S.M.; Patil, A.R.; Fahey, G.C., Jr.; Merchen, N.R.; Wolf, B.W.; Lai, C.S.; Garleb, K.A. Apparent digestibility and glycaemic responses to an experimental induced viscosity dietary fibre incorporated into an enteral formula fed to dogs cannulated in the ileum. Food Chem. Toxicol. 1999, 37, 47-56. [CrossRef]

21. Zentek, J.; Kaufmann, D.; Pietrzak, T. Digestibility and effects on fecal quality of mixed diets with various hydrocolloid and water contents in three breeds of dogs. J. Nutr. 2002, 132, 1679S-1681S. [CrossRef]

22. Gawor, J.; Jodkowska, K.; Jank, M. Effects of an Ascophyllum nodosum formulation on oral health index in dogs and cats. Weter. Prakt. 2013, 10, 74-79.

23. Gawor, J.; Jank, M.; Jodkowska, K.; Klim, E.; Svensonn, U.K. Effects of edible treats containing Ascophyllum nodosum on the oral health of dogs: A double-blind, randomized, placebo-controlled single-center study. Front. Vet. Sci. 2018, 5, 168. [CrossRef]

24. Isidori, M.; Rueca, F.; Trabalza-Marinucci, M. Palatability of extruded dog diets supplemented with Ascophyllum nodosum L. (Fucaceae, Phaeophyceae). J. Appl. Phycol. 2019, 31, 3275-3281. [CrossRef]

25. Laflamme, D. Development and validation of a body condition score system for dogs. Can. Pract. 1997, $22,10-15$.

26. FEDIAF (European Pet Food Industry Federation). Nutritional Guidelines for Complete and Complementary Pet Food for Cats and Dogs. September 2020. Available online: https://fediaf.org/images/FEDIAF_Nutritional_Guidelines_2020_20200917.pdf (accessed on 7 January 2021).

27. AOAC (Association of Official Analytical Chemists). Official Methods of Analysis, 17th ed.; AOAC: Washington, DC, USA, 2000.

28. Vogtmann, H.P.; Frirter, P.; Prabuck, A.L. A new method of determining metabolizability of energy and digestibility of fatty acids in broiler diets. Br. Poult. Sci. 1975, 16, 531-534. [CrossRef] [PubMed]

29. International Organization for Standardization. EN ISO 6869:2000. In Animal Feeding Stuffs. Determination of the Contents of Calcium, Copper, Iron, Magnesium, Manganese, Potassium, Sodium and Zinc-Method Using Atomic Absorption Spectrometry; ISO: Geneva, Switzerland, 2020. Available online: https://www.iso.org/obp/ui/\#iso:std:iso:6869:ed-1:v1:en (accessed on 4 December 2020).

30. Carpenè, E.; Andreani, G.; Ferlizza, E.; Menotta, S.; Fedrizzi, G.; Isani, G. Trace Elements in Home-Processed Food Obtained from Unconventional Animals. Life 2020, 10, 75. [CrossRef]

31. Stefanelli, C.; Carati, D.; Rossoni, C. Separation of N1- and N8-acetylspermidine isomers by reversed-phase column liquid chromatography after derivatization with dansyl chloride. J. Chromatogr. 1986, 375, 49-55. [CrossRef]

32. Muyzer, G.; de Waal, E.C.; Uitterlinden, A.G. Profiling of complex microbial populations by denaturing gradient gel electrophoresis analysis of polymerase chain reaction-amplified genes coding for 16S rRNA. Appl. Environ. Microbiol. 1993, 59, 695-700. [CrossRef]

33. Mühling, M.; Woolven-Allen, J.; Murrell, J.C.; Joint, I. Improved group-specific PCR primers for denaturing gradient gel electrophoresis analysis of the genetic diversity of complex microbial communities. ISME J. 2008, 2, 379-392. [CrossRef]

34. Rinttila, T.; Kassinen, A.; Malinen, E.; Krogius, L.; Palva, A. Development of an extensive set of $16 \mathrm{~S}$ rDNAtargeted primers for quantification of pathogenic and indigenous bacteria in faecal samples by real-time PCR. J. Appl. Microbiol. 2004, 97, 1166-1177. [CrossRef] [PubMed]

35. Malinen, E.; Rinttila, T.; Kajander, K.; Matto, J.; Kassinen, A.; Krogius, L.; Saarela, M.; Korpela, R.; Palva, A. Analysis of the fecal microbiota of irritable bowel syndrome patients and healthy controls with real-time PCR. Am. J. Gastroenterol. 2005, 100, 373-382. [CrossRef]

36. Song, Y.; Liu, C.; Finegold, S.M. Real-time PCR quantitation of clostridia in feces of autistic children. Appl. Environ. Microbiol. 2004, 70, 6459-6465. [CrossRef] [PubMed]

37. Malinen, E. Comparison of real-time PCR with SYBR Green I or 5'-nuclease assays and dot-blot hybridization with rDNA-targeted oligonucleotide probes in quantification of selected faecal bacteria. Microbiology 2003, 149, 269-277. [CrossRef]

38. Sokol, H.; Seksik, P.; Furet, J.P.; Firmesse, O.; Nion-Larmurier, I.; Beaugerie, L.; Cosnes, J.; Corthier, G.; Marteau, P.; Doré, J. Low counts of Faecalibacterium prausnitzii in colitis microbiota. Inflamm. Bowel Dis. 2009, 15, 1183-1189. [CrossRef] 
39. Zannoni, A.; Pietra, M.; Gaspardo, A.; Accorsi, P.A.; Barone, M.; Turroni, S.; Laghi, L.; Zhu, C.; Brigidi, P.; Forni, M. Non-invasive Assessment of Fecal Stress Biomarkers in Hunting Dogs during Exercise and at Rest. Front. Vet. Sci. 2020, 7, 126. [CrossRef] [PubMed]

40. Rattigan, R.; Sweeney, T.; Maher, S.; Thornton, K.; Rajauria, G.; O'Doherty, J.V. Laminarin-rich extract improves growth performance, small intestinal morphology, gene expression of nutrient transporters and the large intestinal microbial composition of piglets during the critical post-weaning period. Br. J. Nutr. 2020, 123, 255-263. [CrossRef] [PubMed]

41. Kadam, S.U.; O’Donnell, C.P.; Rai, D.K.; Hossain, M.B.; Burgess, C.M.; Walsh, D.; Tiwari, B.K. Laminarin from Irish Brown Seaweeds Ascophyllum nodosum and Laminaria hyperborea: Ultrasound Assisted Extraction, Characterization and Bioactivity. Mar. Drugs 2015, 13, 4270-4280. [CrossRef]

42. Patra, J.K.; Lee, S.; Park, J.G.; Baek, K. Antioxidant and antibacterial properties of essential oil extracted from an edible seaweed Undaria pinnatifida. J. Food Biochem. 2017, 41, e12278. [CrossRef]

43. Cian, R.E.; Drago, S.R.; De Medina, F.S.; Martínez-Augustin, O. Proteins and Carbohydrates from Red Seaweeds: Evidence for Beneficial Effects on Gut Function and Microbiota. Mar. Drugs 2015, 13, 5358-5383. [CrossRef]

44. Tanna, B.; Mishra, A. Nutraceutical Potential of Seaweed Polysaccharides: Structure, Bioactivity, Safety, and Toxicity. Compr. Rev. Food Sci. Food Saf. 2019, 18, 817-831. [CrossRef] [PubMed]

45. Lahaye, M.; Michel, C.; Barry, J.L. Chemical, physicochemical and in-vitro fermentation characteristics of dietary fibres from Palmaria palmata (L.) Kuntze. Food Chem. 1993, 47, 29-36. [CrossRef]

46. Karimi, S.H. Effects of Red Seaweed (Palmaria palmata) Supplemented Diets Fed to Broiler Chickens Raised under Normal or Stressed Conditions. Master's Thesis, Dalhousie University, Halifax, NS, Canada, September 2015.

47. Kulshreshtha, G.; Rathgeber, B.; Stratton, G.; Thomas, N.; Evans, F.; Critchley, A.; Hafting, J.; Prithiviraj, B. Feed supplementation with red seaweeds, Chondrus crispus and Sarcodiotheca gaudichaudii, affects performance, egg quality, and gut microbiota of layer hens. Poult. Sci. 2014, 93, 2991-3001. [CrossRef]

48. Heim, G.; Walsh, A.M.; Sweeney, T.; Doyle, D.N.; O'Shea, C.J.; Ryan, M.T.; O’Doherty, J.V. Effect of Seaweed-Derived Laminarin and Fucoidan and Zinc Oxide on Gut Morphology, Nutrient Transporters, Nutrient Digestibility, Growth Performance and Selected Microbial Populations in Weaned Pigs. Br. J. Nutr. 2014, 111, 1577-1585. [CrossRef] [PubMed]

49. Michiels, J.; Skrivanova, E.; Missotten, J.; Ovyn, A.; Mrazek, J.; De Smet, S.; Dierick, N. Intact brown seaweed (Ascophyllum nodosum) in diets of weaned piglets: Effects on performance, gut bacteria and morphology and plasma oxidative status. J. Anim. Physiol. Anim. Nutr. 2012, 96, 1101-1111. [CrossRef]

50. Circuncisão, A.R.; Catarino, M.D.; Cardoso, S.M.; Silva, A.M.S. Minerals from Macroalgae Origin: Health Benefits and Risks for Consumers. Mar. Drugs 2018, 16, 400. [CrossRef]

51. Sartor, R.B. Gut microbiota: Optimal sampling of the intestinal microbiota for research. Nat. Rev. Gastroenterol. Hepatol. 2015, 12, 253-254. [CrossRef]

52. Swanson, K.S.; Grieshop, C.M.; Flickinger, E.A.; Healy, H.P.; Dawson, K.A.; Merchen, N.R.; Fahey, G.C., Jr. Effects of Supplemental Fructooligosaccharides Plus Mannanoligosaccharides on Immune Function and Ileal and Fecal Microbial Populations in Adult Dogs. Arch. Tierernahr. 2002, 56, 309-318. [CrossRef]

53. Kraehenbuhl, J.P.; Neutra, M.R. Molecular and cellular basis of immune protection of mucosal surfaces. Physiol. Rev. 1992, 72, 853-879. [CrossRef]

54. Fagarasan, S. Evolution, development, mechanism and function of IgA in the gut. Curr. Opin. Immunol. 2008, 20, 170-177. [CrossRef]

55. Sutherland, D.B.; Suzuki, K.; Fagarasan, S. Fostering of advanced mutualism with gut microbiota by Immunoglobulin A. Immunol. Rev. 2016, 270, 20-31. [CrossRef]

56. Frei, R.; Akdis, M.; O'Mahony, L. Prebiotics, probiotics, synbiotics, and the immune system: Experimental data and clinical evidence. Curr. Opin. Gastroenterol. 2015, 31, 153-158. [CrossRef] [PubMed]

57. Yang, C.; Mogno, I.; Contijoch, E.J.; Borgerding, J.N.; Aggarwala, V.; Li, Z.; Siu, S.; Grasset, E.K.; Helmus, D.S.; Dubinsky, M.C.; et al. Fecal IgA Levels Are Determined by Strain-Level Differences in Bacteroides ovatus and Are Modifiable by Gut Microbiota Manipulation. Cell Host Microbe 2020, 27, 467-475.e6. [CrossRef] [PubMed]

58. Lomax, A.R.; Calder, P.C. Prebiotics, immune function, infection and inflammation: A review of the evidence. Br. J. Nutr. 2009, 101, 633-658. [CrossRef] [PubMed]

59. Swanson, K.S.; Grieshop, C.M.; Flickinger, E.A.; Bauer, L.L.; Healy, H.P.; Dawson, K.A.; Merchen, N.R.; Fahey, G.C., Jr. Supplemental fructooligosaccharides and mannanoligosaccharides influence immune function, ileal and total tract nutrient digestibilities, microbial populations and concentrations of protein catabolites in the large bowel of dogs. J. Nutr. 2002, 132, 980-989. [CrossRef] [PubMed]

60. Benyacoub, J.; Czarnecki-Maulden, G.L.; Cavadini, C.; Sauthier, T.; Anderson, R.E.; Schiffrin, E.J.; von der Weid, T. Supplementation of food with Enterococcus faecium (SF68) stimulates immune functions in young dogs. J. Nutr. 2003, 133, 1158-1162. [CrossRef] [PubMed]

61. Verlinden, A.; Hesta, M.; Hermans, J.M.; Janssens, G.P. The effects of inulin supplementation of diets with or without hydrolysed protein sources on digestibility, faecal characteristics, haematology and immunoglobulins in dogs. Br. J. Nutr. 2006, 96, 936-944. [CrossRef] 
62. Theodoro, S.S.; Putarov, T.C.; Tiemi, C.; Volpe, L.M.; de Oliveira, C.A.F.; Glória, M.B.A.; Carciofi, A.C. Effects of the solubility of yeast cell wall preparations on their potential prebiotic properties in dogs. PLoS ONE 2019, 14, e0225659. [CrossRef]

63. Gaspardo, A.; Zannoni, A.; Turroni, S.; Barone, M.; Sabetti, M.C.; Zanoni, R.G.; Forni, M.; Brigidi, P.; Pietra, M. Influence of Lactobacillus kefiri on Intestinal Microbiota and Fecal IgA Content of Healthy Dogs. Front. Vet. Sci. 2020, 7, 146. [CrossRef]

64. Ndeh, D.; Gilbert, H.J. Biochemistry of complex glycan depolymerisation by the human gut microbiota. FEMS Microbiol. Rev. 2018, 42, 146-164. [CrossRef]

65. Mathieu, S.; Touvrey-Loiodice, M.; Poulet, L.; Drouillard, S.; Vincentelli, R.; Henrissat, B.; Skjåk-Bræk, G.; Helbert, W. Ancient acquisition of "alginate utilization loci" by human gut microbiota. Sci. Rep. 2018, 8, 8075. [CrossRef] [PubMed]

66. Sweeney, T.; O’Doherty, J.V. Marine macroalgal extracts to maintain gut homeostasis in the weaning piglet. Domest. Anim. Endocrinol. 2016, 56, S84-S89. [CrossRef]

67. Dierick, N.; Ovyn, A.; De Smet, S. Effect of feeding intact brown seaweed Ascophyllum nodosum on some digestive parameters and on iodine content in edible tissues in pigs. J. Sci. Food Agric. 2009, 89, 584-594. [CrossRef]

68. Gardiner, G.E.; Campbell, A.J.; O’Doherty, J.V.; Pierce, E.; Lynch, P.B.; Leonard, F.C.; Stanton, C.; Ross, R.P.; Lawlor, P.G. Effect of Ascophyllum nodosum extract on growth performance, digestibility, carcass characteristics and selected intestinal microflora populations of grower-finisher pigs. Anim. Feed Sci. Technol. 2008, 141, 259-273. [CrossRef]

69. Bhattacharya, T.; Ghosh, T.S.; Mande, S.S. Global Profiling of Carbohydrate Active Enzymes in Human Gut Microbiome. PLoS ONE 2015, 10, e0142038. [CrossRef] [PubMed] 